\title{
Aeroponics for propagation of horticultural plants: an approach for vertical farming
}

\begin{abstract}
Aeroponics is the technique of growing plant in soilless system in which roots hanging in the air acquire nutrition from spraying of nutrient mist. Although aeroponics was developed initially for the study of root system and related aspects by researchers, its paramount success in commercial crop production and large scale clonal propagation made soilless culture and vertical farming a sustainable concept for future. The technique is superior in terms of water use efficiency, less time and space requirement, seasonal independence, disease free plant propagation, large scale plant production etc. than the conventional methods of propagation. Thus it is widely being utilized in the field of horticulture as well as forestry also.
\end{abstract}

Keywords: aeroponics, horticulture, nutrient mist
Volume 2 Issue 6 - 2018

\author{
Udit Sharma, Meena Barupal, NS Shekhawat, \\ Vinod Kataria \\ Biotechnology Lab, Department of Botany (UGC-CAS), Jai \\ Narain Vyas University, India
}

\begin{abstract}
Correspondence: Vinod Kataria,Assistant Professor, Biotechnology Lab, Department of Botany (UGC-CAS), Jai Narain Vyas University, Jodhpur, Rajasthan, India, Email vinodkataria2002@gmail.com
\end{abstract}

Received: November 23, 2017 | Published: December 20, 2018

\section{Introduction}

Aeroponics is a farming technique involving plant cultivation in an enclosed chamber by aeration of roots through micro-spray of aqueous nutrient mist. The word aeroponic is derived from aer (air) and ponos (Labour) of the Greek. ${ }^{1}$ Technique of aeroponics might be influenced by natural phenomenon of hanging roots of orchids in air and absorbing nutrients and moisture. Nevertheless the earlier report concerning the root development apple plant through spraying was published by Barker. ${ }^{2}$ The absence of aggregates provided a fillip to the studies concerning roots of plants since it was easy to procure entire root structure without any mechanical damage as in case of soil and other aggregates. Later, some other researchers also developed the techniques of growing plants with their hanging roots absorbing water and nutrients from vapor/mist. ${ }^{3-5}$ The term 'aeroponics' was coined by F.W. Went in 1957 for the air-growing process while growing the coffee and tomato crops through the same technique. ${ }^{6}$ Though researchers have experimented with several crop plants grown in aeroponics system for various aspects of plant growth and development, the aeroponics apparatus for commercial use was first manufactured by R J Stoner's company GTi in 1983 and marketed as "Genesis rooting system". $7 \mathrm{R} \mathrm{J}$ Stoner is considered as "father of american aeroponics technology". Now the technique has gained paramount success in horticultural as well as research arena.

Aeroponics is more advantageous than the conventional techniques of propagation i.e. lesser time and space requirement, year round crop production in controlled environment (irrespective of season), limited water consumption due to recycling process, completely organic farming as no need of fertilizers and pesticides, healthy (more nutrient availability) and disease free plants products, large scale clonal production for commercial and conservation purposes, easy access to root system reducing labor cost in case of root crops. ${ }^{8}$

\section{Technical setup of aeroponics}

A typical aeroponic unit consists of closed styrofoam chamber in which plant shoots are inoculated in holes made on styrofoam sheet and emerging roots remain dangled in the air. The chamber might be lined with black polysheet in order to assist in maintenance of optimum humidity and darkness in the chamber. Plants cuttings in aeroponics are misted through the nozzles which are evenly spaced and fixed into
PVC pipes for supply of nutrient solution. The pipeline is connected to the motor which pumps the nutrient solution at high pressure. To regulate the nutrient spraying for set time interval, a digital timer is connected to the pump. Space between nozzles and their pressure, spacing of styrofoam holes, pumping capacity of motor, duration of nutrient spraying and time gap between two subsequent sprays may vary according to the scale of aeroponics unit setup and cultivated plants. Nutrient solution dribbling from the suspended roots in the tank is pumped back to the water tank and recycled. In order to ensure the check of contaminating microbes affecting plant growth, nutrient solution is changed after certain time intervals depending upon the filling capacity of nutrient tank and growth of microbes. Infected plants are removed to check the spread of disease in other plants.

\section{Horticultural aspect of aeroponics propagation}

According to the International Society for Horticulture Science (ISHS) the horticultural crops include fruits, nuts and vegetable producing crops, medicinal and aromatic plants and plants of ornamental as well as landscape value. Aeroponics has been utilized for the production of various vegetable crops i.e. Cucumis sativum ${ }^{9}$ Lactuca sativa ${ }^{10,11}$ Solanum lycopersicum ${ }^{12,13}$ and leafy vegetables. ${ }^{14,15}$ Moreover, large scale production of potato seed tubers ${ }^{16-18}$ and yam (Dioscoria sp.) tuber production ${ }^{19}$ was also successfully achieved using this technique. Plants of ornamental value such as croton, geranium, philodendron, dracaena, carnation etc, ${ }^{20}$ chrysanthemum $^{21}$ and poinsettia ${ }^{22}$ have also been studied using this technique. Enhanced growth and root nodulation was observed in Acacia mangium (an important legume tree of timber and landscaping value) through aeroponic culture. ${ }^{23}$ Aeroponics is also being utilized for the production of subtropical and temperate region crops in the tropical environment while manipulating their root zone temperature. ${ }^{24}$

Application of aeroponics in medicinal plant cultivation has also been reported in recent years. Cultivation of medicinal rhizomes i.e. ginger (Zingiber officinale) and high valued root crops i.e. burdock (Arctium lappa), yerba mansa (Anemopsis Californica). ${ }^{25}$ A new compound namely 2,3-Dihydrowithaferin A-3ß-O-sulfate (prodrug of withaferin A) was reported in Withania somnifera grown aeroponically. ${ }^{26}$ Mehandru et al. ${ }^{27}$ reported the clonal propagation 
of three threatened medicinal asclepiads i.e. Caralluma edulis, Leptadenia reticulata and Tylophora indica using aeroponic culture. They observed the higher rooting percentage in stem cuttings grown aeroponically as compared to soil conditions. In a different study Salachas et al..$^{28}$ analyzed the effect of available root zone volume on yield as well as nutritional quality of cultivated holy basil (Ocimum basilicum) in an aeroponic system. Medicinal plants grown on aeroponic culture have also been evaluated for their antibacterial, antiplasmodial as well as cytotoxic properties. ${ }^{29}$

\section{Conclusion and Future aspects}

In conclusion, farming of horticultural crops as well as other aspects of plant propagation i.e. conservation threatened species and clonal propagation of trees could be successfully achieved through aeroponics in controlled environment. The technique could be a practical solution for commercial farming in the anthropocene where world is facing huge scarcity of fresh water and agricultural land to meet the food demand of 7.6 billion. Moreover, it could be the way forward for sustainable and productive farming technique in space.

\section{Acknowledgment}

Udit Sharma gratefully acknowledges University Grants Commission for financial assistance in the form of Junior and Senior Research Fellowship (JRF and SRF).

\section{Conflicts of interest}

Authors declare that they have no conflict of interest.

\section{References}

1. Barker BTP. Studies on root development. Long Ashton Res Station Ann Report. 1921:9-57.

2. Carter WA. A method of growing plants in water vapor to facilitate examination of roots. Phytopathology 32: 623-625.Klotz LGA (1944) A simplified method of growing plants with roots in nutrient vapors. Phytopathology. 1942;34:507-508.

3. Vywan MC, Travell GF. A method of growing trees with their roots in a nutrient mist. Ann Rep East Malling Res Sta. 1953;95-98.

4. Went FW. The Experimental Control of Plant Growth. Chronica Botanica Co., Waltham, Mass. 1957;81-83.

5. Stoner RJ. Aeroponics versus bed and hydroponic propagation. Flor Rev. 1983;1(173):4477.

6. Pagliarulo C, Hayden AL. Potential for greenhous aeroponic cultivation ofmedicinal root crops. Statistics: Red List of South Africa plants version. 2002

7. Park HS, Chiang MH, Park HS. Effects of form and concentration ofnitrogen in aeroponic solution on growth, chlorophyll, nitrogen contents andenzyme activities in Cucumis sativum L. plant. $J$ Korean Soc Hortic Sci. 1997;38 642-646.

8. He J, Lee SK. Growth and photosynthetic responses of three aeroponically grown lettuce cultivars (Lactuca sativa $\mathrm{L}$.) to different root zone temperatures and growth irradiances under tropical aerial conditions. J Hortic Sci Biotechnol. 1988;73:173-180.

9. Demsar J, Osvald H, Vodnik D. The effect of light - dependent application of Nitrate on the growth of aeroponically grown Lettuce (Lactuca sativa L.). J Amer Soc Hort Sci. 2004;129(4):570-575.

10. Gysi C, Allmen F. Balance of water and nutrients in tomatoes grown on soil less systems. Agralforschung. 1997;4:1.
11. Biddinger EJ, Liu CM, Joly RJ, et al. Physiological andmolecular responses of aeroponically grown tomato plants to phosphorous deficiency. J Am Soc Hortic Sci. 1998;123:330-333.

12. Bohme M, Pinker I. Asian leafy vegetables and herbs cultivated in substrate culture and aeroponics in green house. proc. is on growing media \& soilless cultivation. Acta Hort. 2004;1034.

13. Chandra S, Khan S, Avula B, et al. Assessment of total phenolic and flavonoid content, antioxidant properties, and yield of aeroponically and conventionally grown leafy vegetables and fruit crops: a comparative study. Evid Based Complement Alternat Med. 2014;1741-427X.

14. Kim HS, Lee EM, Lee MA, et al. Production of high quality potato plantlets by autotrophic culture for aeroponic systems. J Korean Soc Hortic Sci. 1999;123:330-333.

15. Farran I, Mingo CAM. Potato minituber production using aeroponics: Effects of plant density and harvesting intervals. Am J Potato Res. 2006; $83: 47-53$.

16. Muthoni J,Mbiyu M, Kabira JN. Upscaling production of certified potato seed tubers in Kenya: Potential of aeroponics technology. $J$ Hortic. 2011;3(8):238-243.

17. Rykaczewska $\mathrm{K}$. The potato minituber production from microtubers in aeroponic culture. Plant Soil Environ. 2016;62:210-214.

18. Norbert M, Balogun M, Asiedu R, et al. Yam propagation using ‘Aeroponics' technology. Annu Res Rev Biol. 2014;24:3894-3903.

19. Nir I. Growing plants in aeroponics growth system. In Symposium on Substrates in Horticulture other than Soils In Situ. 1981;126: 435-448.

20. Molitor HD, Fischer M, Popadopoulos AP. Effect of several parameters on the growth of chrysanthemum stock plants in aeroponics. In international symposium on growing media and hydroponics. 1999; 481:179-186.

21. Scoggins HL, Mills HA. Poinsettia growth, tissue nutrient concentration, and nutrient up take as influenced by nitrogen form and stage of growth. J Plant Nutr. 1988;21:191-198.

22. Martin LF, Lee SK, Tham FY, et al. A new approach to enhance growth and nodulation of Acacia mangium through aeroponic culture. Biol Fertil soils. 1997;25(1):7-12.

23. He J. Mineral nutrition of aeroponically grown subtropical and temperate crops in the tropics with manipulation of root-zone temperature at different growth irradiances. Plant Stress. 2010;4:14-30.

24. Hayden AL. Aeroponic and hydroponic systems for medicinal herb, rhizome and root crops. Hortic Sci. 2006; 41(3):536-538.

25. Xu Y-M, Marron MT, Seddon E, et al. 2,3-Dihydrowithaferin A-3b-OSulfate, a new potential prodrug of withaferin A from Aeroponically Grown Withania somnifera. Bioorg Med Chem. 2009;17:2210-2214.

26. Mehandru P, Shekhawat NS, Rai MK, et al. Evaluation of aeroponics for clonal propagation of Caralluma edulis, Leptadenia reticulata and Tylophora indica - three threatened medicinal Asclepiads. Physiol Mol Biol Plants. 2014;20:365-373.

27. Salachas G, Savvas D, Argyropoulou K, et al. Yield and nutritional quality of aeroponically cultivated basil as affected by the available rootzone volume. Emir J Food Agric. 2015;27(12):911-918.

28. Kumari A, Baskaran P, Chukwujekwu JC, et al. The changes in morphogenesis and bioactivity of Tetradenia riparia, Mondia whitei and Cyanoptis speciosa by an aeroponic system. Ind Crops Prod. 2016;84:199-204. 